\title{
The Link Between Innovativeness and Market Orientation in Beekeeping Enterprises
}

\author{
Anca A. POPOVICI ${ }^{1 *}$, Liviu Al. MĂRGHITAȘ ${ }^{1}$, Daniel S. DEZMIREAN ${ }^{1}$, Marioara ILEA ${ }^{2}$ \\ ${ }^{1)}$ Department of Apiculture and Sericulture, Faculty of Animal Science and Biotechnologies, University \\ of Agricultural Sciences and Veterinary Medicine, 3-5 Calea Mănăştur, 400372, Cluj-Napoca, Romania; \\ 2) Department of Economic Sciences, Faculty of Horticulture, University of Agricultural Sciences and \\ Veterinary Medicine, 3-5 Calea Mănăştur, 400372, Cluj-Napoca, Romania; \\ *Corresponding author, email: anca.popovici@usamvcluj.ro
}

Bulletin UASVM Animal Science and Biotechnologies 72(2) / 2015

Print ISSN 1843-5262; Electronic ISSN 1843-536X

DOI:10.15835/buasvmcn-asb:11403

\begin{abstract}
Innovativeness within beekeeping enterprises reflects their propensity to support new ideas and creative processes that will result in new products. The orientation towards customers in beekeeping enterprises involves identifying, understanding and monitoring customers. The results of the present study demonstrate the fact that there is a positive link between innovativeness and market orientation in the beekeeping enterprises under study.
\end{abstract}

Keywords: innovation, customer orientation, bee products

\section{INTRODUCTION}

Innovativeness is the predisposition to engage in creativity and experimentation through the introduction of new products/services, as well as technological leadership via R\&D in new processes (Rauch et al., 2009). Innovative firms introduce new products and services that are more attuned to current and emerging market needs, being able to quickly enter into new markets (Morris et al., 2011). Market orientation reflects the extent to which firms establish the satisfaction of customer needs and wants as an organizing principle of the firm (Jaworski and Kohli, 1993). The concept of market orientation implies both responsive market orientation, which addresses the expressed needs of customers, and proactive market orientation, which addresses the latent needs of customers (Narver et al., 2004). Banterle et al. (2011) show that, in the food sector, the innovativeness of SMEs should meet consumer preferences.

\section{AIMS AND OBJECTIVES}

The purpose of the present research is to determine whether there is a connection between innovativeness and market orientation in beekeeping enterprises in France and Romania.

\section{MATERIALS AND METHODS}

Data were collected by means of an email survey from July until October 2014. A structured questionnaire was sent to the owners of 1,300 apicultural enterprises in France and the same number in Romania. This resulted in 100 valid responses from France and 160 from Romania to be used in the statistical analysis. The data were analysed using SPSS statistical program v. 19. Innovativeness was assessed using three items adapted from the original Covin and Slevin (1989) measure, using a five-point Likert-type scale. The three items were: "The enterprise has companyspecific innovative products that it currently sells", "The enterprise invests in the development of new products", "The enterprise has marketed new product lines during the past 5 years". Market orientation was measured using four items of the MORTN scale developed by Deshpande and Farley (1998): "We continually monitor customers to find new ways to improve customer satisfaction", "Our 
strategy for competitive advantage is based on our understanding of customers' needs", "We poll our customers at least once per year to assess the quality of our products", "Our business objectives are driven primarily by customer satisfaction".

The association between innovativeness and market orientation was tested using Pearson $\chi^{2}$ (Chi square) test. The following two hypotheses are proposed:

$\mathrm{H}_{0}$ : There is no relationship between innovativeness and market orientation.

$\mathrm{H}_{1}$ : There is a relationship between innovativeness and market orientation.

\section{RESULTS AND DISCUSSION}

Following the statistical analysis, the null hypothesis is rejected, as the significance threshold is below 0.05 in the case of both French beekeeping enterprises (Pearson Correlation 0.532, Sig. (2-tailed) - $0.000 \mathrm{~N}-100$ ) and Romanian beekeeping enterprises (Pearson Correlation 0.286, Sig. (2-tailed) - 0.000, N - 160). Therefore, Pearson's correlation demonstrates the fact that there is a significant positive relationship between innovativeness and market orientation in beekeeping enterprises in both countries.

Beekeeping enterprises should not rely solely on the expressed needs of customers, but also consider the latent needs of their customers. Selling innovative products, of superior quality and being customer-oriented are the main factors that ensure the success of beekeeping enterprises. Beekeeping enterprises that develop innovative bee products place themselves in a favorable position within their industry and identify changing market conditions that competitors have not yet recognized. The managers of these enterprises should be aware of the processes involved by the launch of a new product, given that these enterprises have limited resources.

\section{CONCLUSION}

Beekeeping enterprises contribute to the maintenance and creation of jobs and influence the local economic development. Innovativeness and market orientation can help beekeeping enterprises gain a competitive advantage. The existence of a significant positive relationship between innovativeness and market orientation is due to the fact that innovative bee products should provide value to customers.

Acknowledgements. This paper was published under the frame of European Social Fund, Human Resources Development Operational Programme 2007-2013, project no. POSDRU/159/1.5/S/132765.

\section{REFERENCES}

1. Banterle A, Cavaliere A, Carraresi L, Stranieri S (2011). Innovativeness in food small business: What is its relationship with marketing? Agricultural Economics Czech 57(10): 474-483.

2. Covin JG, Slevin DP (1989). Strategic management of small firms in hostile and benign environments. Strategic Management Journal 10(1):75-98.

3. Deshpande R, Farley J (1998). Measuring market orientation: generalization and synthesis. Journal of Market Focused Management 2(3):213-232.

4. Jaworski BJ, Kohli AK (1993). Market orientation: antecedents and consequences. Journal of Marketing 57:53-70.

5. Morris MH, Kuratko DF, Covin JG (2011). Corporate Entrepreneurship \& Innovation (3rd ed.). Mason: SouthWestern/Cengage Publishers

6. Narver JC, Slater SF, MacLachlan DL (2004). Responsive and proactive market orientation and new-product success. Journal of Product Innovation Management 21(5):334-347.

7. Rauch A, Wiklund J, Lumpkin GT, Frese M (2009). Entrepreneurial orientation and business performance: an assessment of past research and suggestions for the future. Entrepreneurship Theory and Practice 33(3):761787. 